\title{
SYARAT-SYARAT YANG DILAKUKAN DALAM PENGAJUAN KARYA INTELEKTUAL UNTUK MENDAPATKAN HAK PATEN
}

\author{
EKA MEI RISTIANTI \\ 165100091
}

Fakultas Komputer, 448757154

ekameiristianti.student@umitra.ac.id

\begin{abstract}
Istilah "paten" sering kita dengar banyak dipakai oleh masyarakat luas, dan bahkan tak jarang di salahpahami sebagai padanan dari istilah " Hak Atas Kekayaan Intelektual " itu sendiri. Namun sesungguhnya, paten hanyalah salah satu dari sekian banyak bentuk perlindungan HAKI. Paten adalah perlindungan HAKI bagi karya intelektual yang bersifat teknologi, atau dikenal juga dengan istilah invensi, dan mengandung pemecahan/solusi teknis terhadap masalah yang terdapat pada teknologi yang telah ada sebelumnya.

Invensi paten dapat berupa produk ataupun proses, sebgai contoh pembakaran pada mesin kendaraan bermotor yang bertujuan untuk menghasilkan emisi gas buang yang ramah lingkungan. baik metode dan proses bagaimana pembakaran tersebut dilakukan, dan mesin yang menerapkan metode dan proses pembakaran itu, keduanya dapat dipatenkan masing masing sebagai proses dan paten produk.

Hak paten hanya diberikan kepada yang pertama kali mengajukan permohonan yang setidaknya sudah dilengkapi syarat minimum pengajuannya, sehingga berhak mendapatkan tanggal penerimaan ( filing date ). Paten juga bersifat teritorial, yang artinya hak paten hanya berlaku dinegara dimana permohonan paten di ajukan dan diberi.
\end{abstract}




\section{A. INTRODUCTION}

\section{Apa itu paten ?}

Istilah "paten" sering kita dengar banyak dipakai oleh masyarakat luas, dan bahkan tak jarang di salahpahami sebagai padanan dari istilah " Hak Atas Kekayaan Intelektual " itu sendiri. Namun sesungguhnya, paten hanyalah salah satu dari sekian banyak bentuk perlindungan HAKI. Paten adalah perlindungan HAKI bagi karya intelektual yang bersifat teknologi, atau dikenal juga dengan istilah invensi, dan mengandung pemecahan/solusi teknis terhadap masalah yang terdapat pada teknologi yang telah ada sebelumnya.

Invensi paten dapat berupa produk ataupun proses, sebgai contoh pembakaran pada mesin kendaraan bermotor yang bertujuan untuk menghasilkan emisi gas buang yang ramah lingkungan . baik metode dan proses bagaimana pembakaran tersebut dilakukan, dan mesin yang menerapkan metode dan proses pembakaran itu, keduanya dapat dipatenkan masing masing sebagai proses dan paten produk.

\section{Syarat-syarat untuk karya} intelektual agar dapat dipatenkan

Kategori suatu karya dan penemuan dapat dipatenkan berdasarkan karakteristik tertentu. Dengan kata lain, tidak semua hasil penemuan bisa dipatenkan. Karya/penemuan yang dapat dipatenkan harus memenuhi syarat secara substantis. Berikut syaratnya :

\section{Bersifat baru}

Hasil karya intelektual belum pernah dipublikasikan terlebih dahulu. Baik di publikasikan di media apapun. Adapun langkah yang harus segera di ukur agar memperoleh hak paten, dengan mengajukan permohonan, akan memperoleh tanggal penerimaan. Jika karya intelektual dipublikasikan sebelum memperoleh tanggal penerimaan, maka permohonan bisa gagal. 
2. Bersifat inventif

Prinsip memperoleh paten

HAKI bersifat inventif, atau kemampuan untuk menciptakan, merancang sesuatu yang sebelumnya belum pernah ada. Paten hanya diberikan pada penemu yang memiliki person skilled in the art.

3. Bersifat aplikatif

Maksud Aplikatif hasil penelitian yang ditemukan dapat dilakukan secara berulang-ulang. Dapat juga diartikan memiliki tingkat kemanfatan bagi masyarakat. Semakin hasil penemuannya digunakan masyarakat luas, mengindikasikan bahwa penemuannya berhasil sebagai solusi atas permasalahan yang muncul. Karya intelektual memiliki syarat yang konsisten, tidak mudah berubah-ubah .
Berikut contoh prosedur untuk pengajuan hak paten

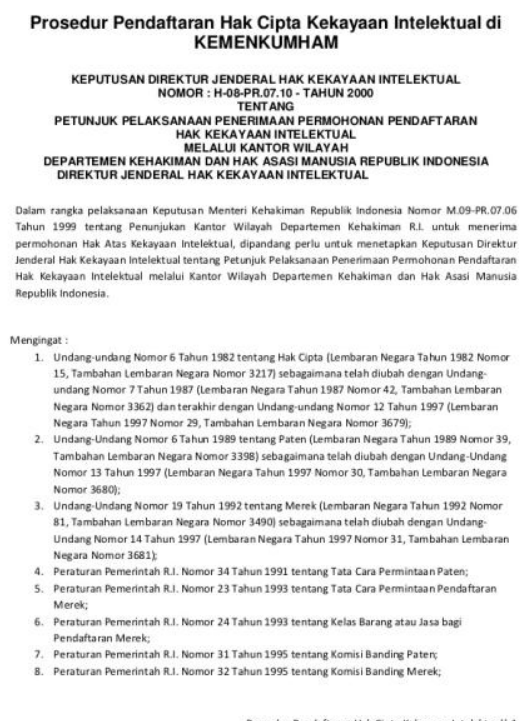

Berikut catatan untuk memperoleh hak paten

Pemilik karya intelektual disebut dengan istilah inventor. Inventor bisa dilakukan secara individu maupun kelompok. Inventor lebih mudah mendapatkan hak paten atas hasil penemuan karya intelektual mereka, sedangkan untuk diluar inventor terlebih dahulu memperoleh pengalihan hak secara tertulis dari sang inventor. 
Apabila ada pihak lain yang memperoleh pengalihan hak dari inventor akan meiliki hak paten selama 20 tahum hak eksklusif tersebut akan menjadi publik domain. Public domain diperuntunkan untuk masyarakat umum, tentu saja tetap melakukan proses ijin pada pemegang hak paten.

Hak paten dalam HAKI bersifat teritorial. Dalam hal ini hak paten hanya berlaku $\mathrm{d}$ negara inventor mengajukan permohonan paten. Pengajuan dilakukan dengan mengirimkan surat permohonan ke direktoral jendral Hak Kekayaan Intelektual ( DJHKI ). Apabila inventor memperoleh hak paten di indonesia, maka hak paten yang diperoleh tidak berlaku atau tidak memiliki hak paten di negara lain.

Kewajiban inventor yang memperoleh hak paten HAKI berhak membayar biaya tahunan. Biaya tersebut bagian dari biaya pemeliharaan paten sampai dengan tahun terakhir masa perlindungan. Hak paten akan hilang secara hukum apabila tidak di bayar selama tiga tahun berturut-turut. Besar biaya pemeliharaan hak paten ditetapkan pleh PNBP ( Penerimaan Negara Bukan Pajak ) di kementrian hukum dan HAM.

Biaya pembiayaan terdiri dari beberapa biaya yaitu biaya pook dan biaya per klaim. Periode pembayarn setiap satu tahun sekali, berdasarkan tanggal yang sama dengan pemberian pengajuan paten pertama kali. Dengan kata lain, batas akhir pembayaran jatuh pada tanggal yang sama saat pengajuan.

Hak paten bersifat Time Sensitive Hak paten diberikan pada inventor pertama kali yang mengajukan permohonan paten. Waktu pengajuan permohonan bersifat krusial dan bersifat time-sensitive. Dengan kata lain, apabila ada dua inventor memiliki karya intelektual yang sama persis, maka yang akan diakui adalah inventor yang lebih dahulu mengajukan permohonan.

Hak paten dalam HAKI bagi mereka yang sudah tahu, berbondong-bondong mengajukan permohonan. Biaya 
permohonan hak paten sebesar Rp. 750.000,00. Sekalipun mereka sebenarnya masih ragu untuk memastikannya. Menariknya, ada sebagian yang tidak memperdulikan biaya pendaftaran paten untuk karya intelektual yang tidak komersial. Mereka tetap tidak merasa rugi, karena memperoleh hak paten lebih penting dari sekedar keuntungan secara ekonomi. Mengingat, hak paten tidak dapat dipatenkan lagi apabila sudah dipublikasikan.

\section{Karya intelektual yang tidak dapat dipatenkan}

Karya intelektual yang bersifat kreasi estetika seperti hak cipta dan desain industri relatif mudah memperoleh hak paten. Termasuk penemuan metode program komputer, presentasi mengenai informasi yang ditemukan lebih mudah memperoleh ijin paten. Meskipun demikian, ada pula karya intelektual yang ternyata tidak dapat dipatenkan. Berikut penjelasannya :

1. Karya intelektual tidak menentang peraturan hak atas kekayaan intelektual , diantaranya tidak mengumumkan karya sebelum mengajukan permohonan.

2. Hasil karya intelektual tidak bertentanagan degan peraturan perundang-undangan.

3. Hasl karya juga tidak menentang moralitas agama mengandung RAS dan menganggu ketertiban umum.

4. Karya intelektial tidak dalam praktik coba-coba.

5. Karya intelektual bukan termasuk metode-metode dan teori. Misalnya metode pemeriksaan, pengobatan, perawatan, pembedahan, dan pengobatan, termasuk teori dan rumus matematika.

Sehebat apapun rumus menyelesaikan permasalahan, tetap tidak dapat dipatenkan .

\section{B. CONCLUSION}

Dari penjelasan di atas dapat disimpulan bahwa paten adalah salah satu bagian Hak atas Kekayaan Intelektual (HaKI) yang berfungsi 
untuk memlindungi suatu karya seseorang. Karya intelektual

bermacam-macam, mulai yang

bersifat teknologi ( invensi ),

penelitian, seni dan masih banyak lagi. Salah satu contoh karya intelektual invensi yang dapat dipatenkan dapat berupa produk dan proses.

Syarat-syarat untuk karya intelektual agar dapat dipatenkan :

1. Bersifat baru

2. Bersifat inventif

3. Bersifat aplikatif

Adapun karya intelektual yang tidak dapat dipatenkan :

1. Karya intelektual tidak menentang peraturan hak atas kekayaan intelektual .

2. Hasil karya intelektual tidak bertentanagan degan peraturan perundang-undangan.

3. Hasl karya juga tidak menentang moralitas agama mengandung RAS dan menganggu ketertiban umum.

4. Karya intelektial tidak dalam praktik coba-coba.
5. Karya intelektual bukan termasuk metode-metode dan teori.

Hak paten hanya diberikan kepada yang pertama kali mengajukan permohonan yang setidaknya sudah dilengkapi syarat minimum pengajuannya, sehingga berhak mendapatkan tanggal penerimaan ( filing date ). Paten juga bersifat teritorial, yang artinya hak paten hanya berlaku dinegara dimana permohonan paten di ajukan dan diberi.

\section{ACKNOWLEDGEMENT} University Of Indonesia University Of Mitra Indonesia Telkom University University Of Mellbourne Saitama University

\section{REFERENCE (Based ISO 690 )}


A. S. Putra, O. M. Febriani, And B. Bachry, "Implementasi Genetic Fuzzy System Untuk Mengidentifikasi Hasil Curian Kendaraan Bermotor Di Polda Lampung," J. Sist. Inf. Dan Manaj. Basis Data, Vol. 1, No. 1, Pp. 21-30, 2018.

[3] O. M. Febriani And A. S. Putra, "Sistem Informasi Monitoring Inventori Barang Pada Balai Riset Standardisasi Industri Bandar Lampung," J. Inform., Vol. 13, No. 1, Pp. 90-98, 2014.

[4] Putra, Arie Setya. "2018 Artikel Struktur Data, Audit Dan Jaringan Komputer." (2018).

[5] Putra, A. S. (2018, July 17). Paperplain Fundamental Create Application With Borland Delphi 7.0 University Of Mitra Indonesia. Retrieved From Osf.Io/Pbrn9.

\section{E. REFERENCE (Based APA)}

Putra, A. S., Aryanti, D. R., \& Hartati, I. (2018, November). Metode SAW (Simple Additive Weighting) sebagai Sistem Pendukung Keputusan Guru Berprestasi (Studi Kasus: SMK Global Surya). In Prosiding Seminar Nasional Darmajaya (Vol. 1, No. 1, pp. 85-97).

Sari, D. P., Febriani, O. M., \& Putra, A. S. (2018, November). Perancangan Sistem Informasi SDM Berprestasi pada SD Global Surya. In Prosiding Seminar Nasional Darmajaya (Vol. 1, No. 1, pp. 289-294).

Putra, A. S. (2018). Paperplain: Execution Fundamental Create
Application With Borland Delphi 7.0 University Of Mitra Indonesia.

Putra, A. S., Sukri, H., \& Zuhri, K. Sistem Monitoring Realtime Jaringan Irigasi Desa (JIDES) Dengan Konsep Jaringan Sensor Nirkabel. IJEIS (Indonesian Journal of Electronics and Instrumentation Systems), 8(2), 221232.

Darmawan, A., Yuliawati, D., Marcella, O., \& Firmandala, R. (2016). Sistem Absensi dan Pelaporan Berbasis Fingerprint dan SMS Gateway. EXPLORE, 7(1).

Febriani, O. M., Wahyuni, T., \& Yusuf, S. (2017). DESIGN OF WEBSITE-BASED INFORMATION SYSTEM FOR EDOCUMENT ADMINISTRASI IN THE COMMUNITY SERVICE UNIT (A Case Study at Rajabasa District). INTERNATIONAL JOURNAL OF COMPUTERS \& TECHNOLOGY, 16(7), 7010-7020.

Febriani, O. M., \& Wahyuni, T. (2017, October). PERANCANGAN SISTEM E-DOCUMENT ADMINISTRASI LOGBOOK PENELITIAN PADA UNIT LAYANAN DI BANDAR LAMPUNG. In Prosiding Seminar Nasional Darmajaya (Vol. 1, No. 1, pp. 187-194).

Febriani, O. M., \& Permadi, A. B. (2017). Implementasi Sistem Aplikasi Data Bimbingan dan Pelanggaran Siswa pada Sekolah Menengah Atas di Lampung Tengah dengan Metode Analisis dan Desain Sistem Terdistribusi (SSAD). EXPERT, 7(1). 
Febriani, O. M., \& Ambarwati, L. (2015). PERANCANGAN APLIKASI PENGOLAHAN DATA PENJUALAN UKM KELANTING KHAS TELO DESA SIDOHARJO KECAMATAN JATI AGUNG KABUPATEN LAMPUNG SELATAN. Jurnal Teknologi Informasi dan Bisnis Pengabdian Masyarakat Darmajaya, 1(1), 77-95.

Febriani, O. M. (2015). Rancang Bangun Aplikasi Ecommercemenggunakan Freewebstore pada UKM Kelanting di Desa Sidoharjo Lampung Selatan. Prosiding Sembistek 2014, 1(02), 446-458. 